\title{
Somatic Embryogenesis and Organogenesis for Regeneration of Endangered Multipurpose Desert Plant Leptadenia pyrotechnica Forsk. Decne in the Kingdom of Bahrain
}

\author{
Manal Ahmed Sadeq, Malabika Roy Pathak*, Ahmed Ali Salih, Mohammed Abido, \\ Asma Abahussain \\ Plant Tissue Culture Laboratory, Desert and Arid Zone Sciences Program, College of Graduate Studies, Arabian \\ Gulf University, Manama, Kingdom of Bahrain \\ Email: malabikarp@agu.edu.bh
}

Received 2 April 2014; revised 8 June 2014; accepted 26 June 2014

Copyright (C) 2014 by authors and Scientific Research Publishing Inc. This work is licensed under the Creative Commons Attribution International License (CC BY). http://creativecommons.org/licenses/by/4.0/

c) (i) Open Access

\begin{abstract}
Leptadenia pyrotechnica is an important multipurpose endangered plant in the Kingdom of Bahrain with restricted distribution. Nodal explants were cultured on Murashige and Skoog (MS) medium supplemented with different concentrations and combinations of indole acetic acid (IAA) and 6-benzylaminopurine (BAP). Initially, $80 \%$ and $60 \%$ explants responded in direct shoot and callus initiation response respectively in presence of $8.88 \mu \mathrm{M}$ BAP with $5.71 \mu \mathrm{M}$ IAA in modified MS media after two weeks of culture. The highest frequency of plant regeneration was observed in presence of $8.88 \mu \mathrm{M}$ BAP with $1.14 \mu \mathrm{M}$ IAA following organogenic pathway of differentiation. Hundred percent callus proliferation was observed while initial callus developed in presence of 4.44 $\mu \mathrm{M}$ BAP with $2.85 \mu \mathrm{M}$ IAA and was transferred in media containing $4.44 \mu \mathrm{M}, 6.66 \mu \mathrm{M}$ BAP with $2.85 \mu \mathrm{M}$ IAA and 13.32 $\mu \mathrm{M}$ BAP with $5.71 \mu \mathrm{M}$ IAA. The callus derived plants were regenerated following the pathway of indirect somatic embryogenesis. The induction of somatic embryogenesis and plant regeneration from callus was also observed in modified MS media supplemented with 4.44 $\mu \mathrm{M}$ BAP and $2.85 \mu \mathrm{M}$ IAA. The plant regeneration protocol we developed for Leptadenia pyrotechnica will be very beneficial for biodiversity conservation and environment protection of Bahrain. Moreover, the present paper reports for the first time specifically the somatic embryogenesis in this multipurpose desert plant Leptadenia pyrotechnica.
\end{abstract}

${ }^{*}$ Corresponding author.

How to cite this paper: Sadeq, M.A., Pathak, M.R., Salih, A.A., Abido, M. and Abahussain, A. (2014) Somatic Embryogenesis and Organogenesis for Regeneration of Endangered Multipurpose Desert Plant Leptadenia pyrotechnica Forsk. Decne in the Kingdom of Bahrain. American Journal of Plant Sciences, 5, 2342-2353. http://dx.doi.org/10.4236/ajps.2014.515248 


\section{Keywords}

\section{Endangered Plants, Ex Situ Conservation, Leptadenia pyrotechnica, Plant Regeneration, Organogenesis, Somatic Embryogenesis}

\section{Introduction}

The Kingdom of Bahrain is an archipelago consisting of thirty-two islands. It has an arid to extremely arid climate similar to the other countries in the Arabian Peninsula. Still, it is relatively rich in biodiversity with 323 species of flora, and those were important in relation to environment protection and national interest [1]. Those plants are important source of good gene pool in food chain and herbal medicine with long history of adaptability in hot, dry and saline desert islands. Among them, 25\% plants are used as medicinal herb by Bahrainis or by others in the Arabian Peninsula or neighboring countries [2]. The importance of medicinal plants both in drug research and biodiversity conservation is well recognized. Medicinal plants are the good sources of secondary metabolites which are used in pharmaceuticals and cosmetic industry [3] [4]. But the amazing socio-economic development in the Kingdom of Bahrain has caused part of habitat demolition, widespread ecological modification and biodiversity degradation. Hence, many plant species in the Kingdom of Bahrain are threatened and some are endangered [5].

Leptadenia pyrotechnica Fossk. Decne, locally known as “Marakh”, belongs to the family of Asclepiadaceae, is restricted in distribution, in Al-Areen Wildlife Reserve of the Kingdom of Bahrain [6]. It is a perennial, leafless shrub, 1 - 3 meters in height, smooth, slender, green branches with milky latex. Leaf develops in the early stages of growth and but falls off with time of development. The shrub produces yellow colored small edible flowers from February to June. The plant is economically important for its multipurpose uses starting from traditional medicine to fiber, forage and other house hold applications in arid ecosystem [7]. It is used traditionally for the treatment of a variety of inflammation-related disease including rheumatism, asthma, wound healing and tumors [8]. Several studies reported that it has antispasmodic, anti-inflammatory, antihistaminic, antibacterial, hypoglycemic, diuretic, expectorant property and is also found useful in gout and rheumatism [9]-[14].

The application of tissue culture as a conservation tool of the threatened plants has gained huge thrust in the last two decades as one of the process of ex situ conservation strategy [15] [16]. Regeneration of in vitro derived plants may follow either somatic embryogenesis or organogenesis path of differentiation. Organogenesis is characterized by the production of unipolar bud primordial with subsequent development of shoot and roots while in somatic embryogenesis, the bipolar structure resembles a zygote embryo that develops from somatic cell. Somatic embryos may develop directly on somatic cell or indirectly from callus aggregates during the culture of plant cell, tissue or organ [17]. Somatic embryogenesis represents a unique developmental pathway that includes a number of characteristic events: dedifferentiation of cells, activation of cell division, and reprogramming of their physiology, metabolism and gene expression patterns [18] [19]. The phytohormones, auxins and cytokinins are important regulators and play role in the developmental fate of pluripotent plant cells to regenerate plants which is well known but the mechanism is quite complicated [20] [22]. Use of cotyledonary nodes as explants for multiplication of shoots, is the only report of tissue culture in this plant [23]. The objective of this research work was to study the tissue differentiation path of plant regeneration and establishment of plant regeneration protocol for Leptadenia pyrotechnica. The protocol for the establishment of in vitro medicinally important endangered plant will help to get a large number of plants in assisting the conservation of biodiversity in the Kingdom of Bahrain.

\section{Materials \& Methods}

\subsection{Collection of Plant Materials}

Nodal segments from stem part of Leptadenia pyrotechnica plants (Figure 4(a)) growing in Al-Areen Wild Life Park of the Kingdom of Bahrain (Figure 1) were used as explant source for culture initiation.

\subsection{Preparation of Explants}

Surface sterilization of explants were performed following modified method of Pathak and Hamzah [19]. Stem 


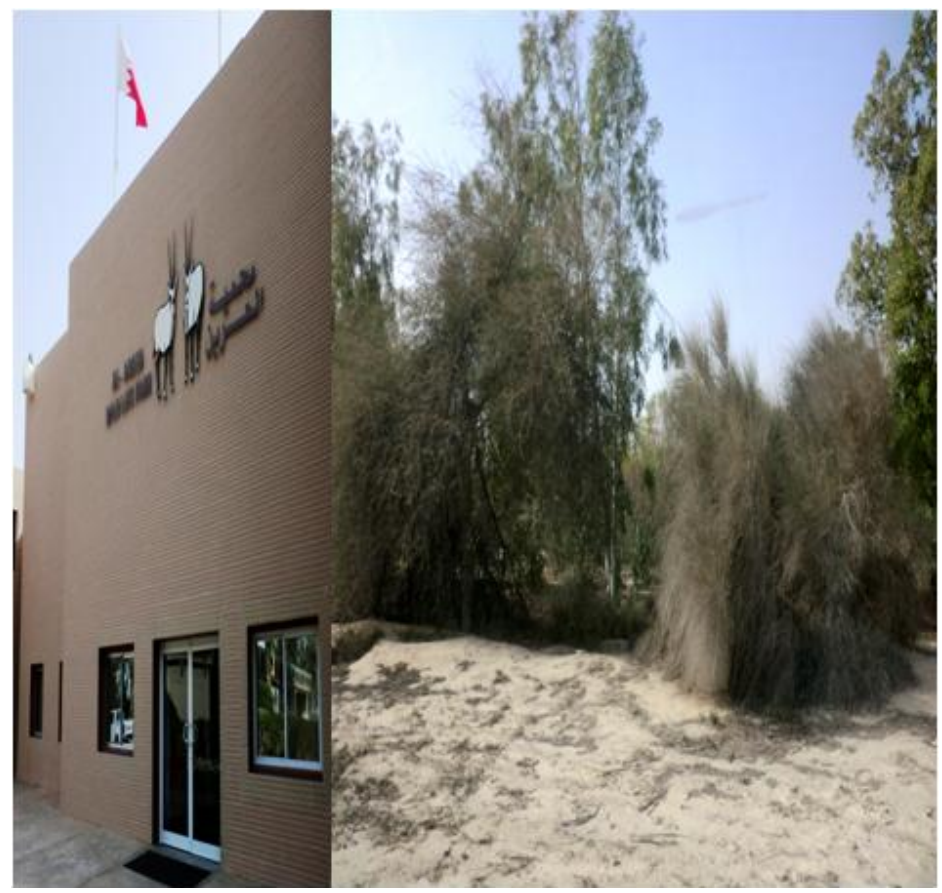

Figure 1. Al-Areen Wildlife Park in the Kingdom of Bahrain.

segments were washed in running tap water for five minutes to remove dust particles from the surface of stem. Then stem segments were kept for five minutes successively in $1 \%$ of Lux solution, $0.5 \%$ of Mercuric chloride solution with few drops of Tween 20, $0.1 \%$ of Copral solution, while the respective solutions were discarded in each step and were washed with autoclaved distilled water thoroughly (5 - 6 times) in each step to remove the used solutions. Then the stem segments were kept in $50 \%(\mathrm{v} / \mathrm{v})$ CLOROX solution (containing $2.625 \%$ hypochlorite) for $15 \mathrm{~min}$ and was washed 5 - 6 times with autoclaved Millipore water to remove hypochlorite nicely. Final washing with $70 \%$ ethanol for 30 seconds was performed before final cut of explants. Finally, the stem segments were sliced with a sterile scalpel blade into smaller segments $(1-2 \mathrm{~cm})$, each with one node and were used as explants.

\subsection{Culture Media and Culture Establishment}

Inorganic salt constituents of Murashige and Skoog (MS) media [24] modified with B5 vitamins [25], 0.3\% of casein hydrolysate and $3 \%$ of sucrose was used throughout the experiments as basal media [26]. Culture media were solidified with $0.8 \%$ agar and sterilized by autoclaving at $121^{\circ} \mathrm{C}$, for 20 minutes at 15 psi. Filter sterilized plant growth regulators (PGRs) were added in autoclaved modified MS media and the media was poured in Magenta vessels of equal volume. MS media without any hormones (1) and with hormones ((2) $4.44 \mu \mathrm{M} \mathrm{BAP} \mathrm{+}$ $2.85 \mu \mathrm{M}$ IAA; (3) $6.66 \mu \mathrm{M}$ BAP + $2.85 \mu \mathrm{M}$ IAA; (4) $8.88 \mu \mathrm{M}$ BAP + $5.71 \mu \mathrm{M}$ IAA; (5) $13.32 \mu \mathrm{M}$ BAP + 5.71 $\mu \mathrm{M}$ IAA) was used for culture initiation.

Surface sterilized nodal explants of suitable size $(1-2 \mathrm{~cm})$ were inoculated in culture bottles containing MS media with different concentrations of PGRs as mentioned above for culture initiation and culture establishment.

\subsection{Culture Maintenance}

Cultures for shoot and callus initiation, growth and regeneration of plantlets were kept under cool white fluorescent light intensity of $2000-2500 \mathrm{LUX}$ for $16 \mathrm{~h}$ light and $8 \mathrm{~h}$ dark photoperiod and a temperature range of $24^{\circ} \mathrm{C}$ $-26^{\circ} \mathrm{C}$ with $70 \%-80 \%$ humidity.

\subsection{Subculture and Plant Regeneration}

Subculture of initially developed callus and shoots were done in modified MS supplemented with different con- 
centration of PGRs. Based on morphological responses, initially regenerated shoots were sub-cultured for multiplication in modified MS media supplemented with hormones (3) $6.66 \mu \mathrm{M}$ BAP $+2.85 \mu \mathrm{M}$ IAA; (4) $8.88 \mu \mathrm{M}$ BAP + $5.71 \mu \mathrm{M}$ IAA; (5) $13.32 \mu \mathrm{M}$ BAP + $5.71 \mu \mathrm{M}$ IAA; (43) $8.88 \mu \mathrm{M}$ BAP + $1.14 \mu \mathrm{M}$ IAA.

Initially developed callus in media containing $4.44 \mu \mathrm{M}$ BAP with $2.85 \mu \mathrm{M}$ IAA were subcultured after two to four weeks in the same media or in media containing (3) $6.66 \mu \mathrm{M}$ BAP + $2.85 \mu \mathrm{M}$ IAA; (4) $8.88 \mu \mathrm{M}$ BAP + $5.71 \mu \mathrm{M}$ IAA; (5) $13.32 \mu \mathrm{M}$ BAP + $5.71 \mu \mathrm{M}$ IAA. The histological study of different stages of somatic cell differentiation was performed (OLYMPUS, Model SZ2-1LST).

The regenerated microshoots developed roots after 4 - 6 weeks of culture in the same media and whole plantlets of $1-5 \mathrm{~cm}$ height were removed from culture media and were washed with autoclaved distilled water to remove media from their rooting surface nicely. Then the plantlets were transplanted in plastic pots containing autoclaved compost soil (1:1 mixture of peat-substrates and potting soil) and were kept in transparent small covered chamber to keep moist. The plants were acclimatized in room conditions at $25^{\circ} \mathrm{C} \pm 3^{\circ} \mathrm{C}, 16 \mathrm{~h}$ light and $8 \mathrm{~h}$ dark photoperiod and watered regularly at 3 days interval.

\subsection{Data Collection and Analysis}

The experiments were carried out by using completely randomized design (CRD) with three replications of each experiment and 3 - 5 explants per replications. Data were collected in 15 days interval after initial culture and later on after 30 days interval. Based on morphological responses of explants, percentage of shoot and callus initiation response, shoot and callus initiation frequency, later on shoot and callus multiplication frequency, plant regeneration capacity, shoot length, root frequency were analyzed based on data collected in each step. Plant regeneration capacity was calculated per explants by counting total number of shoots initiated and their multiplication after second transfer. Statistical analysis of data was carried out using SPSS 17.0 software. Means of 3 replicates per treatment were compared with control as well as multiple treatment groups. Mean comparisons were performed at $\mathrm{P} \leq 0.05$ level of significance using one way analysis of variance (ANOVA) according to Duncan's multiple range test (DMRT) using JMP (version 9) statistical software.

\section{Results and Discussion}

\subsection{Effect of BAP and IAA on Shoot and Callus Initiation Response}

The direct shoot initiation response of $80 \%$ and $70 \%$ was observed in media consisting of $8.88 \mu \mathrm{M}$ BAP with $5.71 \mu \mathrm{M}$ IAA and $6.66 \mu \mathrm{M}$ BAP with $2.85 \mu \mathrm{M}$ IAA respectively after 2 weeks of culture of nodal stem segment of Leptadenia pyrotechnica (Figure 2, Figure 4(d)). The highest callus initiation by $60 \%$ was obtained in media containing $8.88 \mu \mathrm{M}$ BAP and $5.71 \mu \mathrm{M}$ IAA, while media containing $13.32 \mu \mathrm{M}$ BAP and $5.71 \mu \mathrm{M}$ IAA gave a

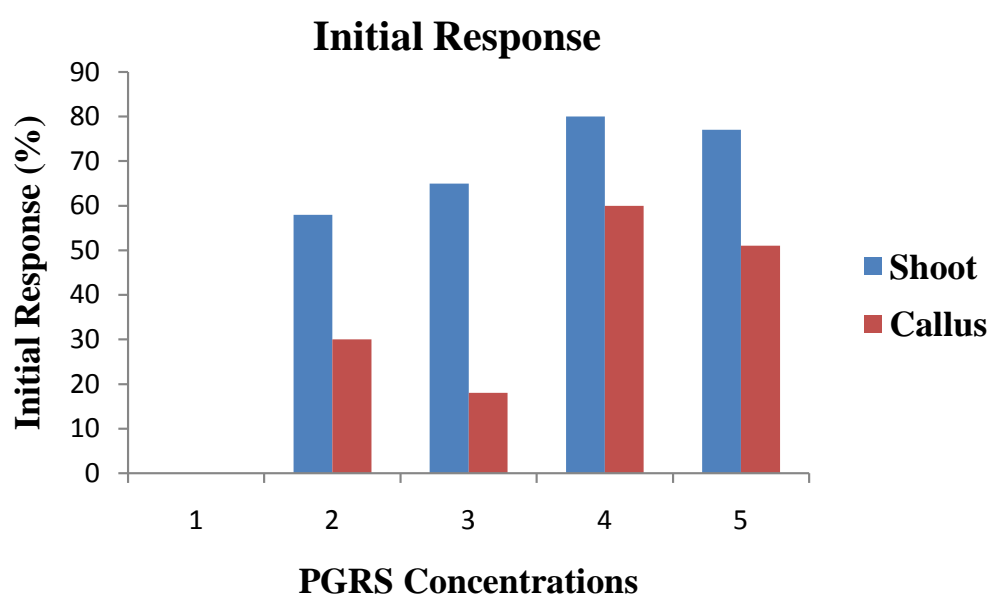

Figure 2. Effect of BAP and IAA supplemented to modified MS media on in vitro shoot and callus initiation response from nodal explants of $L$. pyrotechnica after two weeks of culture initiation. Results are percentage of initial response of explants. 
callus response of $40 \%$ after 2 weeks of culture of nodal stem segments (Figure 2, Figure 4(c)). No shoot and callus initiation was observed in media without any PGRs (Figure 4(b)). The highest shoot initiation frequency was 5.66 followed by 4.33 was observed in media containing $8.88 \mu \mathrm{M}$ BAP with $5.71 \mu \mathrm{M}$ IAA and $6.66 \mu \mathrm{M}$ BAP with $2.85 \mu \mathrm{M}$ IAA respectively after 2 weeks of culture (Figure 3). The highest callus initiation frequency of 2 was followed by 1.5 was observed in $8.88 \mu \mathrm{M}$ BAP with $5.71 \mu \mathrm{M}$ IAA and $13.32 \mu \mathrm{M}$ BAP with $5.71 \mu \mathrm{M}$ IAA respectively after 2 weeks of culture (Figure 3 ). The interactive effects of culture media and mean number of shoots per explant as well as mean number of calli initiation per explant were significant at $0.05 \mathrm{P}$ values (Table 1 and Table 2). Analysis of variance revealed different PGRs concentrations significantly affect shoot and callus induction in different media. The surface sterilization of explants is very essential for its culture establishment, as well as for optimum induction of plantlet regeneration under in vitro condition [27]. The earlier

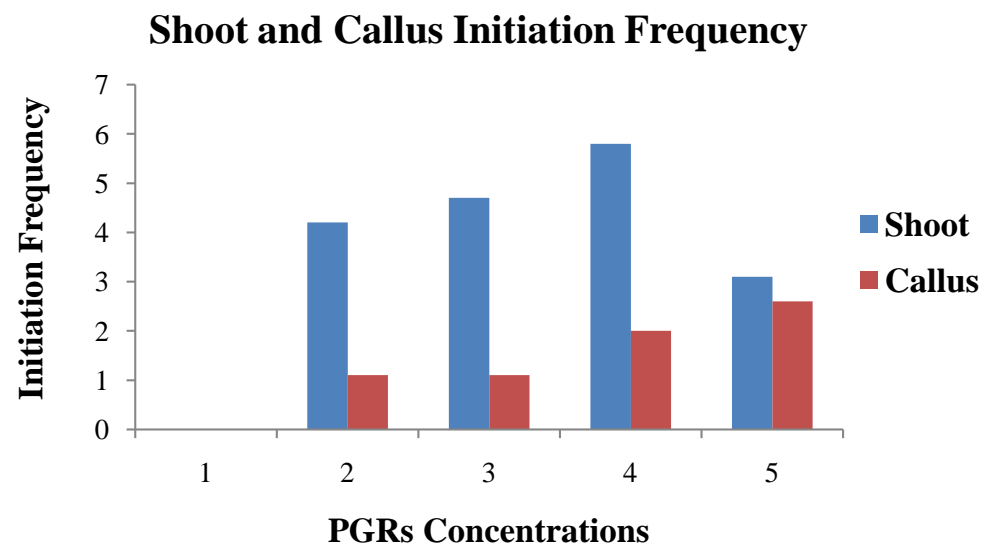

Figure 3. Effect of BAP and IAA supplemented to modified MS medium on in vitro shoot and callus initiation frequency from nodal explants of $L$. pyrotechnica after two weeks of culture. Results are mean \pm S.E.

Table 1. Effect of various growth regulators supplemented to modified MS media on in vitro shoot initiation response from nodal explants of $L$. pyrotechnica after 2 weeks of culture. Results are means of shoots developed per explant of 3 sets of individual experiments. Means followed by the same letter are not significantly different at $\mathrm{P} \leq 0.05$.

\begin{tabular}{cc}
\hline PGRs concentrations & Mean \\
\hline $8.88 \mu \mathrm{M} \mathrm{BAP}+5.71 \mu \mathrm{M} \mathrm{IAA}$ & $5.66 \mathrm{~A}$ \\
$6.66 \mu \mathrm{M} \mathrm{BAP}+2.85 \mu \mathrm{M} \mathrm{IAA}$ & $4.33 \mathrm{~B}$ \\
$4.44 \mu \mathrm{M} \mathrm{BAP}+2.85 \mu \mathrm{M} \mathrm{IAA}$ & $4 \mathrm{~B}$ \\
$13.3 \mu \mathrm{M} \mathrm{BAP}+5.71 \mu \mathrm{M}$ IAA & $3 \mathrm{C}$ \\
Medium without hormones & $0 \mathrm{D}$ \\
\hline
\end{tabular}

Table 2. Effect of various growth regulators supplemented to modified MS medium on in vitro calli initiation response from nodal explants of $L$. pyrotechnica after 2 weeks of culture. Results are means of calli developed per explant of 3 sets of individual experiments. Means followed by the same letter are not significantly different at $\mathrm{P} \leq 0.05$.

\begin{tabular}{cc}
\hline PGRs concentrations & Mean \\
\hline $8.88 \mu \mathrm{M}$ BAP $+5.71 \mu \mathrm{M} \mathrm{IAA}$ & $2 \mathrm{~B} \mathrm{C}$ \\
$13.3 \mu \mathrm{M} \mathrm{BAP}+5.71 \mu \mathrm{M} \mathrm{IAA}$ & $1.66 \mathrm{~B} \mathrm{C}$ \\
$4.44 \mu \mathrm{M} \mathrm{BAP}+2.85 \mu \mathrm{M} \mathrm{IAA}$ & $1 \mathrm{C} \mathrm{D}$ \\
$6.66 \mu \mathrm{M}$ BAP $+2.85 \mu \mathrm{M}$ IAA & $1 \mathrm{C} \mathrm{D}$ \\
Medium without hormones & $0 \mathrm{D}$ \\
\hline
\end{tabular}


studies have revealed that stem internodes were more productive then other explants for shoot regeneration [28] [29] though different explants resulted in production of large number of genetically identical clones in Polianthes tuberose L. [30], Bixa ovellana L. [31]. Bohidar, et al. [32] reported that the combination of auxin and cytokinin are repressible for shoot multiplication and elongation of many other plant species. The addition of BAP and IAA to MS medium is more effective than other hormones which significantly increased the number of shoot induction per explants in most of the genotypes of Melissa officinalis L [33]. The ratio of auxins and cytokinins is an important factor to induce shoots and shoot growth and 1:3 ratio of auxin and cytokinin induced best differentiation response of explants either of shoot initiation or callus iniduction. Similarly, a ratio of auxin and cytokinin 1:2 - 1:3 was more effective in organogenic response and high frequency adventitious shoot induction in Salvia Africana-lutea L. and Phyllanthus amarus respectively [34] [35]. Similarly, in this study, the BAP and IAA in ratio 3:1 performed best both in the shoot and callus initiation. BAP is the most reliable, useful and effective PGR for shoot proliferation, while it has been used for breaking dormancy in several other medicinal plants as observed in other studies [36] [37]. Munazir, et al. [38] reported the effect of auxin and cytokinins as major growth regulators and those influence the phenomena of cell division, callus induction and regeneration in elite wheat varieties.

\subsection{Effect of BAP and IAA on Shoot Multiplication}

The effect of various concentrations of BAP and IAA were compared for initially developed shoots and calli. The highest shoot multiplication frequency by 2.6 was observed in media containing $8.88 \mu \mathrm{M}$ BAP with 1.14 $\mu$ M IAA (Table 3). The development of shoot with callus mass and its multiplication without callus was noticed in media $8.88 \mu \mathrm{M}$ BAP with $1.14 \mu \mathrm{M}$ IAA after one month of culture (Figure 4(e), Figure 4(f)). The effective ratio of BAP and IAA is prominent in regenerating large number of shoots in this plant. Auxins are known to exhibit synergistic, antagonistic and additive interactions with cytokinins at multiple levels depending on the plant species and tissue types in regulating responses [39]. Similarly, the interactions of auxin and cytokinin play important role in organogenic response, shoot multiplication and shoot elongation [30]. The multiple shoots were induced in the culture of the nodal shoot segments of Leptadenia reticulate in presence of BAP and were multiplied in media containing BAP and kinetin [40]. Differential distribution of auxins respond in mediating multiple aspects of organogenesis were reported [21] [41]. Cytokinins modulate auxin-induced organogenesis through its effect on auxin distribution [22]. The lower concentration of IAA $(1.14 \mu \mathrm{M})$ with higher concentration of BAP $(8.88 \mu \mathrm{M})$ triggered the breaking of apical dominance by inhibiting the apical peak on the side bud and stimulated proliferation of axillary shoots. In medicinal plant, Oroxylum indicum, the two cytokinins (BAP and $\mathrm{KI}$ ) were used for direct in vitro regeneration experiment, where BAP induced significantly higher percentage of shoot initiation and mean number of shoots in compare to KI [42].

\subsection{Effect of BAP and IAA on Plant Regeneration and Rooting of Microshoots}

The plant regeneration frequency, shoot length and rooting frequency of microshoots was compared in different media containing various concentrations of BAP and IAA. The highest frequency of 13 plants/explant was observed when initially developed shoots were transferred to media containing $8.88 \mu \mathrm{M}$ BAP with $1.14 \mu \mathrm{M}$ IAA

Table 3. Effect of different concentration of BAP and IAA on shoot multiplication frequency, plant regeneration frequency, shoot length and root development frequency of regenerated plantlets of L. pyrotechnic. (1) Modified MS media without any hormones; (3) $6.66 \mu \mathrm{M}$ BAP + $2.85 \mu \mathrm{M}$ IAA; (4) $8.88 \mu \mathrm{M}$ BAP + $5.71 \mu \mathrm{M}$ IAA; (5) $13.32 \mu \mathrm{M}$ BAP + $5.71 \mu \mathrm{M}$ IAA; (43) $8.88 \mu \mathrm{M}$ BAP $+1.14 \mu \mathrm{M}$ IAA were used for shoot multiplication.

\begin{tabular}{ccccc} 
Name of media & $\begin{array}{c}\text { Shoot multiplication } \\
\text { frequency }\end{array}$ & $\begin{array}{c}\text { Plant regeneration } \\
\text { frequency }\end{array}$ & $\begin{array}{c}\text { Mean shoot length } \\
\text { (mm) }\end{array}$ & $\begin{array}{c}\text { Root frequency of regenerated } \\
\text { plants }\end{array}$ \\
1 & 0 & 0 & $10 \pm 1.1$ & 0 \\
3 & 1.5 & 5 & $10 \pm 1.9$ \\
4 & 0.75 & 3 & $25 \pm 3.2$ & 0.6 \\
43 & 1 & 5 & $45 \pm 2.5$ \\
\hline
\end{tabular}




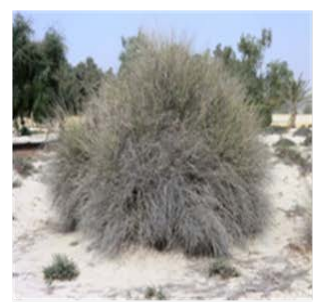

a

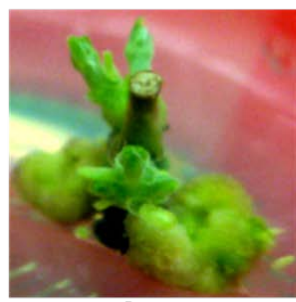

d

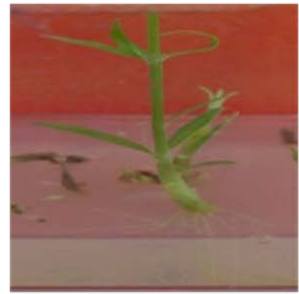

$g$

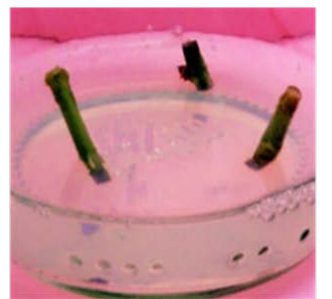

b

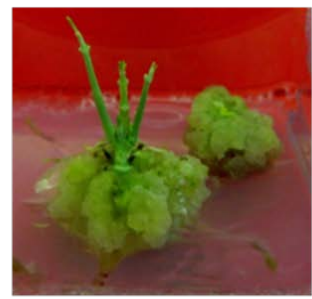

e

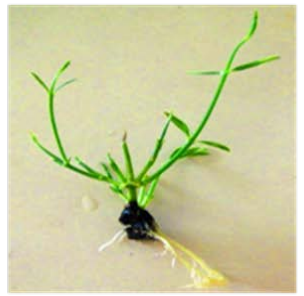

h

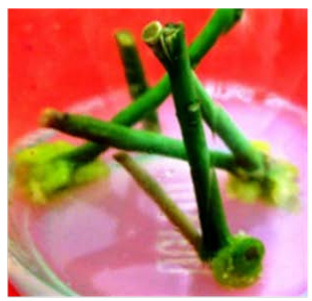

c

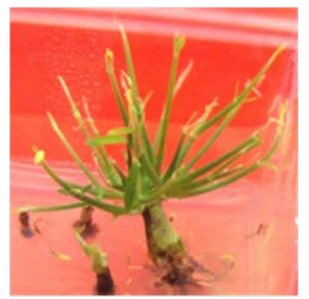

f

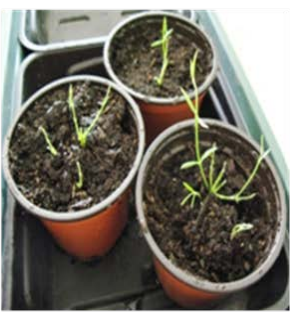

i

Figure 4. Stages of in vitro plant regeneration via direct organogenesis from nodal explants of $L$. pyrotechnica. (a) L. pyrotechnica plants growing in Al-Areen Wild Life Park of Bahrain; (b) Nodal explants are cultured in modified MS medium without hormones; (c) Nodal explants showing callus initiation response in media containing PGRs after two weeks of culture initiation; (d) Shoot initiation response from nodal explants after two weeks of culture; (e), (f) Multiplication of micro-shoots; (g) Regenerated micro-shoot in rooting media developed well defined root system; (h) Rooted plantlet taken out from media (i) Regenerated plantlet growing in soil pots.

(Figure 4(f), Table 3). The plants developed in the same media after transfer showed the highest shoot height and the highest rooting frequency as compared to other media (Figure 4(h) and Figure 4(i), Table 4). The young plants showed well developed leaves and roots (Figure 4(h)). The rooted plants were transferred to soil pots and the pots were kept in small transparent covered chamber to assist good growth under moist condition (Figure 4(i)). Similarly, in Heliotropium kotschyi (Ramram), the highest frequency of shoot regeneration was observed in modified MS media supplemeted with $8.88 \mu \mathrm{M}$ BAP and 5.71 IAA [43]. The highest plant regeneration capacity (2000 - 3000 plant/shoot) of Salvia Africana-lutea L. was observed in presence of high concentration of BAP than IAA (20 or 4:1) after long subculture [34]. The plant regeneration ability was enhanced in low concentration of auxins than cytokinins in the callus culture of Triticum aestivum was reported [44]. The high regenerative capacity was observed in embryogenic callus mass of Iris setosa while MS media were supplemeted with $2.5 \mathrm{mg} / \mathrm{L}^{-1}$ thidiazuron (TDZ) and $0.4 \mathrm{mg} / \mathrm{L}^{-1} \mathrm{NAA}$ [45]. IAA and NAA alone or in combination with BAP, is effective in inducing roots in microshoots of different plant species [46] [47]. While MS medium with IAA is more effective for rooting was observed than other auxins [48]. The combination of IAA and BAP with proper concentration induced shoot initiation, callus induction and plant regeneration to ultimate rooting signal was observed in this study. The phytohormones auxin and cytokinin (CK) are important regulators in controlling the developmental fate of pluripotent plant cells through organogenesis. Organogenesis represents an important competence evolved in plants that allows their physiological and developmental adaptation to changing environmental conditions under control situation. However, the molecular nature of their interaction(s) in control of plant organogenesis is largely unknown [22]. 
Table 4. Effect of BAP and IAA on the multiplication of initially developed calli of $L$. pyrotechnica in media containing $4.44 \mu \mathrm{M}$ BAP with $2.85 \mu \mathrm{M}$ IAA after two weeks of growth. (1) Modified MS media without any hormones; (2) $4.44 \mu \mathrm{M}$ BAP with $2.85 \mu \mathrm{M}$ IAA; (3) $6.66 \mu \mathrm{M}$ BAP + $2.85 \mu \mathrm{M}$ IAA; (4) $8.88 \mu \mathrm{M}$ BAP + $5.71 \mu \mathrm{M}$ IAA; (5) $13.32 \mu \mathrm{M}$ BAP + 5.71 $\mu \mathrm{M}$ IAA were used for callus multiplication.

\begin{tabular}{cccc}
\hline Name of media & Percentage of proliferated callus & $\begin{array}{c}\text { Callus multiplication } \\
\text { frequency }\end{array}$ & Callus growth \\
\hline 1 & 0 & 0 & - \\
2 & 100 & 1 & +++ \\
3 & 100 & 1 & ++ \\
4 & 50 & 0.5 & ++ \\
\hline
\end{tabular}

\subsection{Callus Dedifferentiation, Induction of Somatic Embryogenesis and Plant Regeneration}

Hundred percent callus multiplication was observed while initially developed callus in media containing 4.44 $\mu \mathrm{M}$ BAP with $2.85 \mu \mathrm{M}$ IAA were transferred to media $4.44 \mu \mathrm{M}$ BAP with $2.85 \mu \mathrm{M}$ IAA, $6.66 \mu \mathrm{M}$ BAP with $2.85 \mu \mathrm{M}$ IAA and $13.32 \mu \mathrm{M}$ BAP with $5.71 \mu \mathrm{M}$ IAA (Table 4). The callus transferred in media fortified with 4.44 $\mu \mathrm{M}$ BAP and 2.85 $\mu \mathrm{M}$ IAA showed dedifferentiation of nonembryogenic callus to embryogenic callus and plant development with time. The nonembryogenic callus masses were creamy white to grey color, amorphous and friable in nature (Figure 5(a)). The heterologous proembryonic and embryogenic callus masses were white to greenish in color, compact in nature (Figure 5(b)) and were composed of nodular (Figure 5(c)) and elongated somatic embryos (Figure 5(d)). The somatic embryos showed whole plant development after eight to ten weeks of transfer following the pathway of somatic embryogenesis (Figure 5). Somatic embryos passed through characteristic morphological stages following globular (Figure 5(e)), oblong (Figure 5(f)), enlarged torpedo (Figure 5(g)), heart (Figure 5(h)), cotyledonal (Figure 5(i) and Figure 5(j)) to regenerate whole plants with root (Figures 5(k)-(m)) during six to eight weeks of culture period. It was observed that a discrete zone of the embryogenic callus developed in presence of $4.44 \mu \mathrm{M}$ BAP and $2.85 \mu \mathrm{M}$ IAA which ultimately differentiated and produced several whole plants with fully developed root and shoot (Figure 5). Somatic embryogenesis is the process of plant regeneration where somatic cells under inductive conditions go through a series of morphological and biochemical changes to ensure the formation of somatic embryos [49]. Somatic embrygenesis outline the cellular totipotency which is unique in plant regenetion method with potential biotechnological application in advance plant research [50]. Similar results were also reported during in vitro culture of Oryza sativa [20], Arabidopsis thaliana [51], Caffea arabica [52], wheat [38], showed differentiation of plants from discrete zone of embryogenic callus masses following somatic embryogenesis in presence of higher concentration of cytokines than auxins. In medicinal plant, Rauvolfia serpentine L, the embryogenic callus differentiated into whole plant development in presence of $2 \mathrm{mg} \cdot \mathrm{L}^{-1} \mathrm{BAP}$ and $0.5 \mathrm{mg} \cdot \mathrm{L}^{-1} \mathrm{IAA}$ was reported [53]. In bulbous ornamental plants, Hippeastrum hybridum and Eucharis grandiflora followed both direct and indirect way of somatic embryogenesis in whole plant regeneration where BAP played important role together with naphthalene acetic acid [54]. Somatic embryogenesis with minimal proliferation of callus to somatic embryos and further differentiation into whole plant regeneration in the same culture media with time is the unique observation in this desert plant, Leptadenia pyrotechnic. Somatic embryogenesis has considered a very useful technique for conservation, propagation and multiplication of many endangered medicinal plants [53]-[58].

\section{Conclusion}

Nodal explants showed good response in shoot regeneration. The role of BAP and IAA on shoot initiation and multiplication is prominent. Nodal explants of Leptadenia pyrotechnica responded in plant regeneration following both direct organogenesis and indirect somatic organogenesis, which is very important information in the study of plant cell differentiation and in the establishment of regeneration protocol. Somatic embryogenesis is a very useful technique in micropropagation process for rapid plant propagation, easy plant establishment, quick biomass production in endangered plant conservation and plant improvement program in desert environments. 

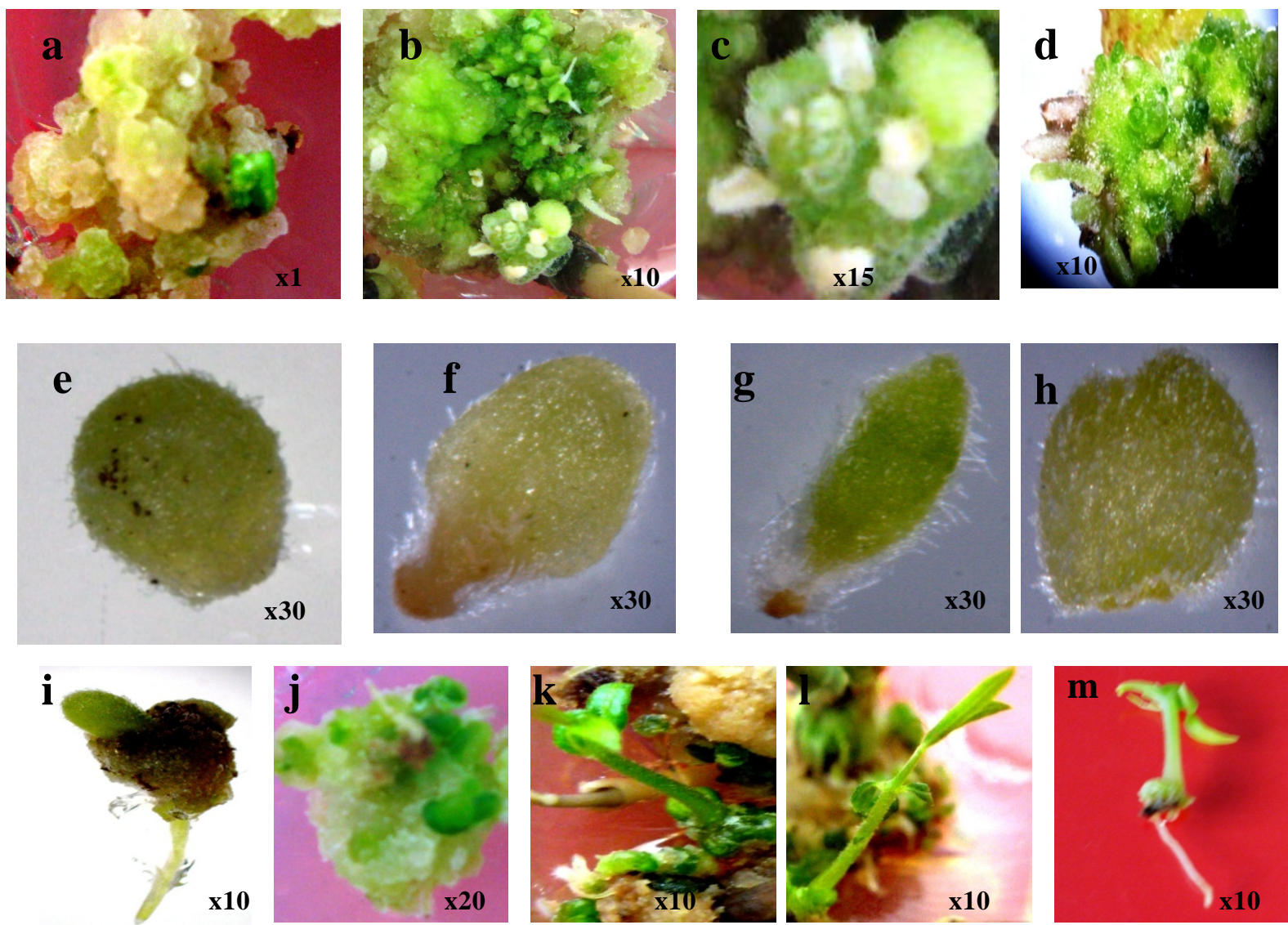

Figure 5. Stage of somatic embryogenesis mediated in vitro plant regeneration of L. pyrotechnica. (a) Non embryogenic calli; (b) Embryogenic calli showing somatic embryos in different stages of development; (c) Embryogenic callus mass showing globular embryo; (d) Elongated, torpedo shaped somatic embryos developed on the surface of embryogenic callus mass; (e) Isolated globular-shaped somatic embryo; (f) Oblong-shaped somatic embryo; (g) Enlarged torpedo shaped somatic embryo; (h) Heart-shaped somatic embryo; ((i), (j)) Germinating somatic embryo with shoot and root differentiation at a time; ((k), (l)) Whole plants with well developed shoot and root developed on callus mass; (m) Plant developed by somatic embryogenesis with well developed strong shoot and root system to transfer in soil.

Considering the great importance of this endangered, multipurpose desert plant in the Kingdom of Bahrain, in vitro culture and plant regeneration are important steps of ex situ conservation strategy.

\section{Acknowledgements}

The work was supported by College of Graduate Studies, Desert and Arid Zone Sciences Program, Arabian Gulf University, Manama, Kingdom of Bahrain.

\section{References}

[1] El-Oqlah, A. and Abbas, J. (1994) A Checklist of Vascular Plants of Bahrain. Dirasat Journal, 21, 95-118.

[2] Jameel, A., Al-Laith, A. and Qaher, M. (2010) Knowledge, Attitudes, and Practices Regarding Medicinal Plants Used by the Indigenous People of Bahrain. Arab Gulf Journal of Scientific Research, 28, 105-117.

[3] Bennett, R.N. and Wallsgrove, R.M. (1994) Secondary Metabolites in Plant Defense Mechanisms. New Phytology, 127, 617-633. http://dx.doi.org/10.1111/j.1469-8137.1994.tb02968.x

[4] Grayer, R.J. and Harborne, J.J. (1994) A Survey of Antifungal Compounds from Higher Plants, 1982-1993. Phytochemistry, 37, 19-42. http://dx.doi.org/10.1016/0031-9422(94)85005-4

[5] Al-Eisawi, D. (2003) Effect of Biodiversity Conservation on Arid Ecosystem with a Special Emphasis on Bahrain. 
Journal of Arid Environments, 54, 81-90. http://dx.doi.org/10.1006/jare.2001.0888

[6] Khanna, A. (2012) Implementation of UNCCD in the GCC Countries. In: Khanna, A., Ed., Global Environmental Governance and Desertification: A Study of Gulf Corporation Council Countries. Concept Publishing Company Pvt. Ltd., New Delhi, 272.

[7] Dagla, H.R., Paliwal, A., Rathore, M.S. and Shekhawat, N.S. (2012) Micropropagation of Leptadenia pyrotechnica (Forsk.) Decne: A Multipurpose Plant of an Arid Environment. Journal of Sustainable Forestry, 31, 283-293. http://dx.doi.org/10.1080/10549811.2011.582831

[8] Khasawneh, A.M., Elwy, M.H., Hamza, A.A., Fawzi, M.N. and Hassan, H.A. (2011) Antioxidant Anti-Lipoxygenase and Cytotoxic Activity of Leptadenia pyrotechnica (Forssk.) Decne Polyphenolic Constituents. Molecules, 16, 75107521. http://dx.doi.org/10.3390/molecules16097510

[9] Aquino, R., Peluso, G., Tommasi, N.D., Simone, F.D. and Pizza, C. (1996) New Polyoxypregnane Ester Derivatives from Leptadenia hastate. Journal of Natural Product, 59, 555-564. http://dx.doi.org/10.1021/np960251e

[10] Abd El-Ghani, M.M. and Amer, W.M. (2003) Soil-Vegetation Relationships in a Coastal Desert Plain of Southern Sinai, Egypt. Journal of Arid Environments, 55, 607-628. http://dx.doi.org/10.1016/S0140-1963(02)00318-X

[11] Cioffi, G., Sanogo, R., Vassallo, A., Dal Piaz, F., Autore, G., Marzocco, S. and Tommasi, N.D. (2006) Pregnane Glycosides from Leptadenia pyrotechnica. Journal of Natural Product, 69, 625-635. http://dx.doi.org/10.1021/np050493r

[12] Panwara, J. and Tarafdarb, J.C. (2006) Distribution of Three Endangered Medicinal Plant Species and Their Colonization with Arbuscular Mycorrhizal Fungi. Journal of Arid Environments, 65, 337-350. http://dx.doi.org/10.1016/j.jaridenv.2005.07.008

[13] Jain, G.C., Jhalani, J.C., Agarwal, S. and Jain, K. (2007) Hypolipidemic and Antiatherosclerotic Effect of Leptadenia pyrotechnica Extracts in Cholestrol Fed Rabbits. Asian Journal of Experimental Science, 21, 115-122.

[14] Munazir, M., Qureshi, R., Arshad, M. and Gulfraz, M. (2012) Antibacterial Activity of Root and Fruit Extracts of Leptadenia pyrotechnica (Asclepiadaceae) from Pakistan. Pakistan Journal of Botany, 44, 1209-1213.

[15] Paunescu, A. (2009) Biotechnology for Endangered Plant Conservation: A Critical Overview. Romanian Biotechnological Letters, 14, 4095-4103.

[16] Khan, S., Al-Qurainy, F. and Mohammad, N. (2012) Biotechnological Approaches for Conservation and Improvement of Rare and Endangered Plants of Saudi Arabia. Saudi Journal of Biological Sciences, 19, 1-11.

[17] Von Arnold, S., Sabala, I., Bozhkov, P., Dyachok, J. and Filonova, L. (2002) Developmental Pathways of Somatic Embryogenesis. Plant Cell, Tissue and Organ Culture, 69, 233-249. http://dx.doi.org/10.1023/A:1015673200621

[18] Yang, X.Y. and Zhang, X.L. (2010) Regulation of Somatic Embryogenesis in Higher Plants. Critical Reviews in Plant Sciences, 29, 36-57. http://dx.doi.org/10.1080/07352680903436291

[19] Pathak, M.R. and Hamzah, R.Y. (2008) An Effective Method of Sonication-Assisted Agrobacterium-Mediated Transformation of Chickpea. Plant Cell, Tissue and Organ Culture, 93, 65-71. http://dx.doi.org/10.1007/s11240-008-9344-6

[20] Ray, M., Ghosh, S. and Ghosh, B. (1996) Plant Regeneration from Embryogenic Calli of Heat Tolerant and Sensitive Cultivars under Thermal Stress. Physiology and Molecular Biology of Plant, 2, 59-66.

[21] Benková, E., Michniewicz, M., Sauer, M., Teichmann, T., Seifertová, D., Jürgens, G. and Friml, J. (2003) Local, EffluxDependent Auxin Gradients a Common Module for Plant Organ Formation. Cell, 115, 591-602. http://dx.doi.org/10.1016/S0092-8674(03)00924-3

[22] Pernisová, M., Klíma, P., Horák, J., Válková, M., Malbeck, J., Soucek, S., Reichman, P., Hoyerová, K., Dubová, J., Jiř́i, F., Eva, Z. and Jan, H. (2009) Cytokinins Modulate Auxin-Induced Organogenesis in Plants via Regulation of the Auxin Efflux. Proceedings of the National Academy of Sciences of the United States of America, 106, 3609-3614. http://dx.doi.org/10.1073/pnas.0811539106

[23] Dagla, H.R., Paliwal, A., Rathore, M.S. and Shekhawat, N.S. (2012) Micropropagation of Leptadenia pyrotechnica (Forsk.) Decne: A Multipurpose Plant of an Arid Environment. Journal of Sustainable Forestry, 31, 283-293. http://dx.doi.org/10.1080/10549811.2011.582831

[24] Murashige, T. and Skoog, F. (1962) A Revised Medium for Rapid Growth and Bioassay with Tobacco Tissue Culture. Physiologia Plantarum, 15, 473-497. http://dx.doi.org/10.1111/j.1399-3054.1962.tb08052.x

[25] Gamborg, O., Miller, R. and Ojimi, K. (1968) Nutrient Requirements of Suspension Cultures of Soybean Root Cells. Experimental Cell Research, 50, 151-158. http://dx.doi.org/10.1016/0014-4827(68)90403-5

[26] Pathak, M.R. and Hamzah, R.Y. (2010) In Vitro Plant Regeneration and Genetic Transformation of Chickpea (Cicer arietinum L). In: Sivakumar, P., Gnanam, R., Khawar, K.M. and Thangadurai, D., Eds., Grain Legume Research: Tissue Culture, Biotechnology and Genetic Engineering, 2, Bio Science Publications, Tamil Nadu, 11-19.

[27] Yeoman, M.M. and Macleod, A.J. (1977) Tissue (Callus) Culture Technique. In: Street, H.E., Ed., Plant Tissue and 
Cell Culture, Blackwell Scientific Publications, Oxford, 31-59.

[28] Chen, C.C., Chen, S.J., Sagare, A.P. and Tsay, H.S. (2001) Adventitious Shoot Regeneration from Stem Internode Explants of Adenophora triphylla (Thunb) A.C. (Campanulaceae)-An Important Medicinal Herb. Botanical Bulletin of Academia Sinica, 42, 1-7.

[29] Turker, A.U., Yucesan, B. and Gurel, E. (2010) Adventitious Shoot Regeneration from Stem Internode Explants of Verbena officinalis L., a Medicinal Plant. Turkish Journal of Biology, 34, 297-304.

[30] Sangavai, C. and Chellapandi, P. (2008) In Vitro Propagation of a Tuberose Plant (Polianthes tuberose L.). Electronic Journal of Biology, 4, 98-101.

[31] Sharon, M., Marie, C.C. and Sharon, M. (2012) In Vitro Culture Studies of Bixa orellana L: III. Plant Regeneration from Roots through Direct and Indirect Somatic Embryogenesis. European Journal of Experimental Biology, 2, 156162.

[32] Bohidar, S., Thriunavoukkarasu, M. and Reo, V. (2008) Effect of Growth Regulators on in Vitro Micropropagation of “Garden Rue” Ruta graveolens L. International Journal of Integrated Biology, 3, 36-43.

[33] Mohebalipour, N., Aharizad, S., Mohammadi, S., Motallebiazar, A. and Arefi, H. (2012) Effect of Plant Growth Regulators BAP and IAA on Micropropagation of Iranian Lemon Balm (Melissa officinalis L.) Landraces. Journal of Food, Agriculture and Environment, 10, 280-286.

[34] Makunga, N. and Staden, J. (2008) An Efficient System for the Production of Clonal Plantlets of the Medicinally Important Aromatic Plant: Salvia Africana-lutea L. Plant Cell, Tissue and Organ Culture, 92, 63-72. http://dx.doi.org/10.1007/s11240-007-9305-5

[35] Sen, A., Sharma, M.M., Grover, D. and Batra, A. (2009) In Vitro Regeneration of Phyllanthus amarus Schun. and Thonn.: An Important Medicinal Plant. Our Nature, 7, 110-115.

[36] Da Silva, S., Sato, A., Luiz, C., Lage, S., Azevedo, A. and Apparecida, E.M. (2005) Essential Oil Composition of Melissa officinalis L. in Vitro Produced under the Influence of Growth Regulators. Journal of the Brazilian Chemical Society, 16, 1387-1390. http://dx.doi.org/10.1590/S0103-50532005000800014

[37] Ghiorghita, G.I., Mafteli, D.E.S. and Nicuta, D.N. (2005) Investigations on the in Vitro Morphgenetic Reaction of Melissa officinalis L. Species. Genetics and Molecular Biology, 5, 119-125.

[38] Munazir, M., Qureshi, R., Ali, M., Rashid, U., Noor, S., Mehmood, K., Ali, S. and Arshad, M. (2010) Primary Callus Induction, Somatic Embryogenesis and Regeneration Studies in Elite Wheat Varieties from Pakistan. Pakistan Journal of Botany, 42, 3957-3965.

[39] Coenen, C. and Lomax, T.L. (1997) Auxin-Cytokinin Interactions in Higher Plants: Old Problems and New Tools. Trends in Plant Science, 2, 351-356. http://dx.doi.org/10.1016/S1360-1385(97)84623-7

[40] Shekhawat, N.S., Kackar, A., Rathore, M.S., Singh, M., Dagla, H.R. and Vinod, A. (2006) Establishment and Economic Evaluation of Micropropagated Jeewanti (Leptadenia reticulate Wight \& Arn.) Plants in Field. Natural Product Radiance, 5, 311-314.

[41] Dubrovsky, J.G., Sauer, M., Napsucialy-Mendivil, S., Ivanchenko, M.G., Friml, J., Shishkova, S., Celenza, J. and Benková, E. (2008) Auxin Acts as a Local Morphogenetic Trigger to Specify Lateral Root Founder Cells. Proceedings of the National Academy of Sciences of the United States of America, 105, 8790-8794. http://dx.doi.org/10.1073/pnas.0712307105

[42] Gokhale, M. and Bansal, Y.K. (2009) Direct in Vitro Regeneration of a Medicinal Tree Oroxylum indicum (L.) Vent. through Tissue Culture. African Journal of Biotechnology, 8, 3777-3781.

[43] Sadeq, M.A., Pathak, M.R., Ahmed, A.S., Abido, M. and Abahussain, A. (2014) Highly Efficient in Vitro Regeneration Method of Endangered Medicinal Plant Heliotropium kotschyi (Ramram) in the Kingdom of Bahrain. Ameriacn Journal of Plant Sciences, 5, 736-747. http://dx.doi.org/10.4236/ajps.2014.55088

[44] Varshney, V., Kant, T., Sharma, V.K., Rao, A. and Kothari, S.L. (1996) High Frequency Plant Regeneration from Immature Embryo Cultures of Triticum aestivum and T. durum. Cereal Research Communication, 24, 409-416.

[45] Radojevic, L. and Subotic, A. (1992) Plant Regeneration of Iris setosa Pall. Through Somatic Embryogenesis and Organogenesis. Journal of Plant Physiology, 139, 690-696. http://dx.doi.org/10.1016/S0176-1617(11)81712-8

[46] Roy, A. and Bhattacharya, S. (2008) An Improved Micropropagation of Eclipta alba by in Vitro Priming with Chlorocholine Chloride. Plant Cell, Tissue and Organ Culture, 92, 315-319. http://dx.doi.org/10.1007/s11240-007-9328-y

[47] Saini, R., Sharma, A., Sharma, M.M. and Batra, A. (2011) Impacts of Phytohormones in Micropropagation of Medicinally Potent Plant: Boerhavia diffusa L. International Journal of Pharmaceutical Sciences Review and Research, 8, 85-89.

[48] Ujjwala, J.S. (2007) In Vitro Regeneration of Aloe barbadensis. Biotechnology, 6, 601-603. http://dx.doi.org/10.3923/biotech.2007.601.603 
[49] Komamine, A., Murata, N. and Nomura, K. (2005) Mechanisms of Somatic Embryogenesis in Carrot Suspension Cultures-Morphology, Physiology, Biochemistry and Molecular Biology. In Vitro Cellular \& Developmental BiologyPlant, 41, 6-10. http://dx.doi.org/10.1079/IVP2004593

[50] Schmidt, E., Guzzo, D.F., Toonen, M.M. and De Vries, S.C. (1997) A Leucine-Rich Repeat Containing Receptor-Like Kinase Marks Somatic Plant Cells Competent to Form Embryos. Development, 124, 2049-2062.

[51] Ikeda-Iwai, M., Satoh, S. and Kamada, H. (2002) Establishment of a Reproducible Tissue Culture System for the Induction of Arabidopsis Somatic Embryos. Journal of Experimental Botany, 53, 1575-1580. http://dx.doi.org/10.1093/jxb/erf006

[52] Quiroz-Figueroa, F.R., Fuentes-Cerda, C.F.J., Rojas-Herrera, R. and Loyola-Vargas, V.M. (2002) Histological Studies on the Developmental Stages and Differentiation of Two Different Somatic Embryogenesis Systems of Coffea arabica. Plant Cell Report, 20, 1141-1149. http://dx.doi.org/10.1007/s00299-002-0464-x

[53] Singh, P., Singh, A., Shukla, A., Singh, L., Pande, V. and Nailwal, T. (2009) Somatic Embryogenesis and in Vitro Regeneration of an Endangered Medicinal Plant Sarpgandha (Rauvolfia serpentina. L). Life Science Journal, 6, 74-79.

[54] Mujib, A., Banerjee, S. and Ghosh, P.D. (2005) Origin, Development and Structure of Somatic Embryos in Selected Bulbous Ornamentals: Bap as Inducer. In: Mujib, A. and Samaj, J., Eds., Plant Cell Monograph. Somatic Embryogenesis, Springer-Verlag, Berlin, 15-24.

[55] Sahrawat, A.K. and Chand, S. (2001) Continuous Somatic Embryogenesis and Plant Regeneration from Hypocotyl Segments of Psoralea corylifolia Linn., an Endangered and Medicinally Important Fabaceae Plant. Current Science, 81, 25-27.

[56] Choi, Y.E., Kim, J.W. and Yoon, E.S. (1999) High Frequency of Plant Production via Somatic Embryogenesis from Callus or Cell Suspension Cultures in Eleutherococcus senticosus. Annals of Botany, 83, 309-314. http://dx.doi.org/10.1006/anbo.1998.0827

[57] Munoz, T.L. and Garay, R.B. (1996) Somatic Embryogenesis in the Threatened Cactus Turbinicarpus pseudomacrochele (Buxbaum and Backeberg). Journal of the Professional Association for Cactus Development, 1, 36-38.

[58] Verma, M. and Bansal, Y.K. (2012) Induction of Somatic Embryogenesis in Endangered Butterfly Ginger Hedychium coronarium J. Koenig. Indian Journal of Experimental Biology, 50, 904-909. 
Scientific Research Publishing (SCIRP) is one of the largest Open Access journal publishers. It is currently publishing more than 200 open access, online, peer-reviewed journals covering a wide range of academic disciplines. SCIRP serves the worldwide academic communities and contributes to the progress and application of science with its publication.

Other selected journals from SCIRP are listed as below. Submit your manuscript to us via either submit@scirp.org or Online Submission Portal.
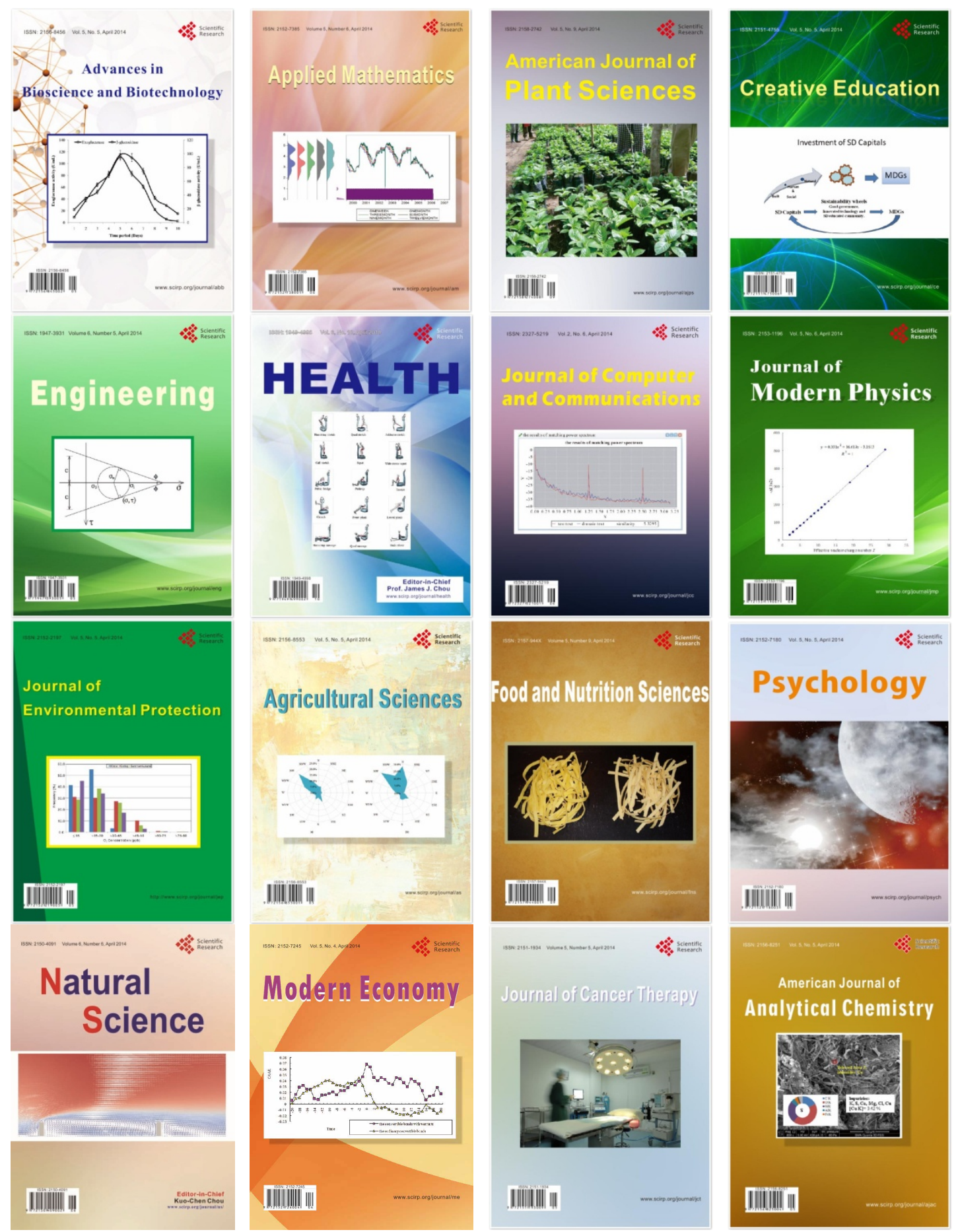